\section{THE DETECTION OF A PLASMID IN STREPTOMYCES AMBOFACIENS KA-1028 AND ITS POSSIBLE INVOLVEMENT IN SPIRAMYCIN PRODUCTION}

Sir:

The role of plasmids as a genetic determinant of antibiotic production has been suggested by numerous investigations ${ }^{1 \sim 3)}$. We have studied the isolation, structural determination and biosynthesis of 16-membered macrolides ${ }^{4,5)}$. Of particular interest regarding the production of 16-membered macrolides is the observation that many related components are coproduced by the same strain; this phenomenon is an important problem in development of the production of single components to be evaluated as practical antibiotics. A study of the involvement of plasmids in 16-membered macrolide synthesis may provide us with fundamental information concerning genetic control of macrolide production.

In this communication we report the detection of plasmid DNA in a spiramycin-producing strain, Streptomyces ambofaciens and provide evidence for the possible involvement of the plasmid in the biosynthesis of spiramycin which is a 16-membered macrolide with a well characterized biosynthetic scheme ${ }^{5}$.

S. ambofaciens KA-1028 (ISP-5053) produced $100 \mu \mathrm{g} / \mathrm{ml}$ of spiramycin when fermentation was performed in $500 \mathrm{ml}$ SAKAGUCHI flasks with 100 $\mathrm{ml}$ of medium consisting of $1.0 \%$ glucose, $1.0 \%$ dried yeast, $0.5 \% \mathrm{NaCl}, 1.0 \% \mathrm{CaCO}_{3}$, and $0.1 \%$ $\mathrm{NaNO}_{3}\left(\mathrm{pH} 7.5\right.$ ), with aeration at $27^{\circ} \mathrm{C}$ for 72 hours. Spiramycin non-producing strains were obtained by treatment of KA-1028 with 10 $\mu \mathrm{g} / \mathrm{ml}$ of acriflavine ${ }^{6)}$ at a frequency of $10 \%$. Plasmid DNA from the parent strain KA-1028 and the spiramycin non-producing strain AF-30 (obtained by acriflavine treatment) were analyzed by $\mathrm{CsCl}$-ethidium bromide equilibrium centrifugation and agarose gel electrophoresis. Seed culture of strains for plasmid analysis were incubated in $5 \mathrm{ml}$ of medium containing $1.0 \%$ glucose, $0.4 \%$ glycine, $0.4 \%$ casamino acid, $0.02 \%$ yeast extract, $0.1 \% \mathrm{MgSO}_{4} \cdot 7 \mathrm{H}_{2} \mathrm{O}, 0.01 \%$ $\mathrm{CaCl}_{2} \cdot 2 \mathrm{H}_{2} \mathrm{O}, 1.0 \% 1 \mathrm{~m}$ phosphate buffer $(\mathrm{pH}$ 7.2 ) and $0.4 \%$ of a solution of trace elements containing $40 \mathrm{mg} \mathrm{ZnCl}, 200 \mathrm{mg} \mathrm{FeCl}_{2} \cdot 6 \mathrm{H}_{2} \mathrm{O}$, $10 \mathrm{mg} \mathrm{CuCl} \cdot 2 \mathrm{H}_{2} \mathrm{O}, 10 \mathrm{mg} \mathrm{MnCl} \cdot 4 \mathrm{H}_{2} \mathrm{O}, 10 \mathrm{mg}$ $\left(\mathrm{NH}_{4}\right)_{6} \mathrm{Mo}_{7} \mathrm{O}_{24} \cdot \mathrm{H}_{2} \mathrm{O}$ and $10 \mathrm{mg} \mathrm{Na}_{2} \mathrm{~B}_{4} \mathrm{O}_{7} \cdot 10 \mathrm{H}_{2} \mathrm{O}$ in one liter, at $27^{\circ} \mathrm{C}$ for 72 hours. The seed culture was transferred to $10 \mathrm{ml}$ of the same medium with glycerol replaced glucose, without yeast extract and containing $5 \mu \mathrm{Ci}$ of $\left[\right.$ methyl ${ }^{3} \mathrm{H}$ ] thymidine per $\mathrm{ml}$ and $200 \mu \mathrm{g}$ of uridine per $\mathrm{ml}$. Incubation was continued for 24 hours at $27^{\circ} \mathrm{C}$. Mycelia were harvested on Millipore filters and washed with $20 \mathrm{ml}$ of TES buffer $(50 \mathrm{~mm}$ $\mathrm{NaCl}, 5$ mм EDTA, 30 mм Tris-HCl, pH 8.0) and homogenized with a Teflon tissue homogenizer. The homogenized cells were lysed by incubation with $1 \mathrm{mg}$ of lysozyme per $\mathrm{ml}$ for 10 minutes at $37^{\circ} \mathrm{C}$ followed by the addition of 1.5 $\mathrm{ml}$ of $0.75 \%$ sodium lauryl sarcosinate solution. A cleared lysate was obtained by the treatment of the lysate with $200 \mu \mathrm{g}$ of proteinase $\mathrm{K}$ per ml at $37^{\circ} \mathrm{C}$ for 1 hour and centrifugation at 30,000 $\times g$ for 30 minutes. Two $\mathrm{ml}$ of the cleared lysate was mixed with $5.00 \mathrm{~g}$ of $\mathrm{CsCl}$ and $2.76 \mathrm{ml}$ of TES buffer, and $0.5 \mathrm{ml}$ of ethidium bromide solution $(4.67 \mathrm{mg} / \mathrm{ml}$ in water) in a polyallomer tube. The contents of the tube were covered with liquid paraffin, and centrifuged with Hitachi RP-65 angle rotor for 36 hours at $36,000 \mathrm{rpm}$. Forty fractions were collected for the estimation of distribution of radioactivity. The cleared

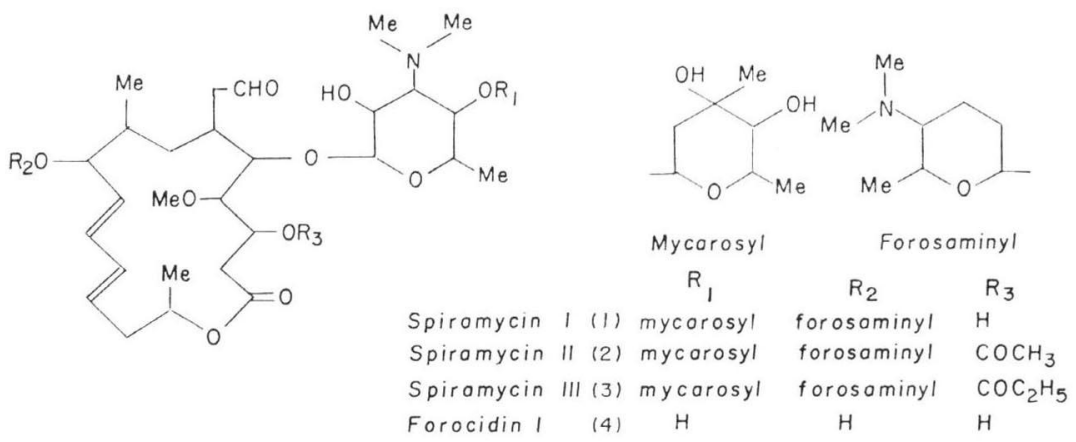


Fig. 1. CsCl-ethidium bromide equilibrium centrifugation of a cleared lysate of strain KA-1028.

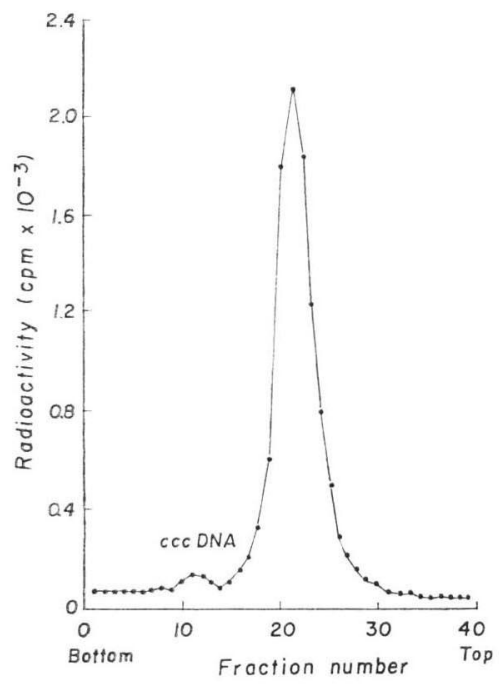

Fig. 2. Agarose gel electrophoresis,

(A) a cleared lysate of strain S-1.

(B) a cleared lysate of strain AF-30.

(C) a cleared lysate of strain KA-1028 (parent strain).

(D) a portion $(40 \mu 1)$ of fractions of denser DNA satellite band (fractions $10 \sim 13$ in Fig. 1).

(A)

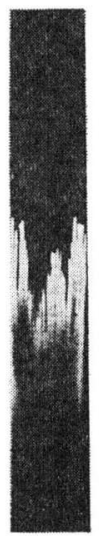

(B)

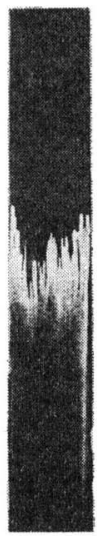

(C)

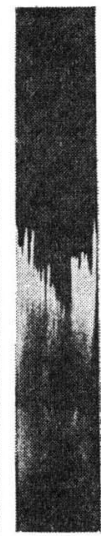

(D)

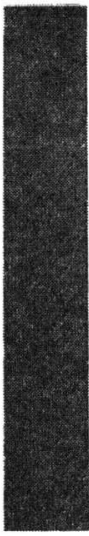

CCC DNA

Chromosoma 7 DNA

Fig. 3. Bioconversion of forocidin I to spiramycins by the spiramycin-non-producing strain, AF-30.

The chromatograms developed with $\mathrm{CHCl}_{3}-\mathrm{MeOH}-1.5 \mathrm{~N}$ aqueous ammonia $(2: 1: 1$, bottom layer $)$ were scanned at $232 \mathrm{~nm}$. Spiramycin II and III show identical Rf values under these conditions. Forocidin I was added after 48 hour of cultivation of the strain AF-30.

(A) Strain KA-1028

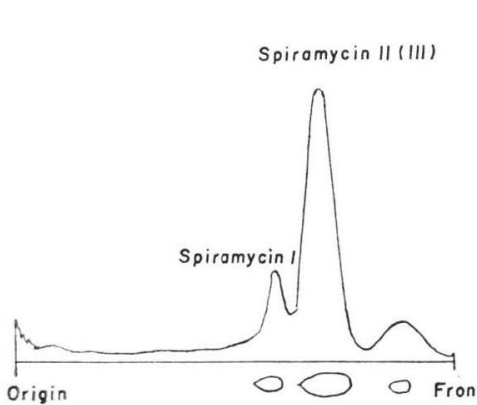

(B) Strain AF- 30

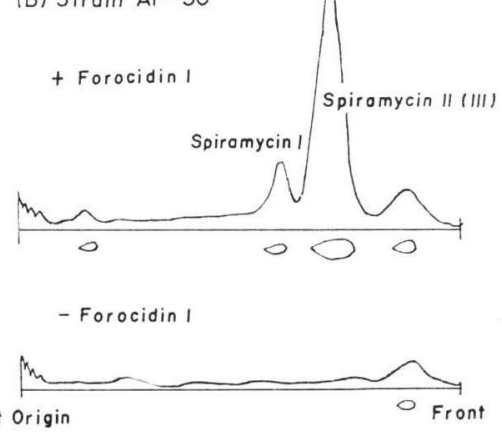

lysates were also analyzed by agarose gel electrophoresis according to the procedure of MEYERS et al. ${ }^{7}$

The presence of plasmid DNA (ccc DNA) could be detected by both analytical methods in the spiramycin-producing strain KA-1028 as shown in Figs. 1 and 2. However, the plasmid DNA was not detected in the cleared lysate from the spiramycin-non-producing strains AF-30 and $\mathrm{S}-1$.

In order to ascertain if a plasmid-controlled function was involved in the biosynthetic path- way to spiramycin, we examined the plasmid cured strain for its ability to convert forocidin I (4) which is an important intermediate in the biosynthesis of spiramycin ${ }^{5}$, into spiramycin II (2). Fig. 3 indicates silica-gel thin-layer chromatograms of extracts obtained from 72-hour fermentation broths of KA-1028 and AF-30 scanned with dual wave-length chromatogram scanner. The chromatogram of the extract from KA-1028 (Fig. 3A) indicates two peaks corresponding to spiramycin II (2) and spiramycin I (1), respectively. Strain AF-30 did not produce 
spiramycins as shown in Fig. 3B. However, the production of spiramycins in strain AF-30 could be detected when forocidin I (4) was added to the fermentation broth, at 48-hour cultivation (Fig. 3B). Conversion of forocidin I (4) to spiramycin II (2) was also observed in the majority of spiramycin-non-producing strains derived from strain KA-1028 by curing the plasmid by acriflavine treatment. Table 1 summarizes information on strains KA-1028, AF-30 and S-1; the latter was randomly chosen from spiramycin-non-producing strains spontaneously derived from KA-1028. Formation of soluble pigment and aerial mycelium, both of which presumably require some plasmid-coded function were absent in strains AF-30 and S-1 (Table 1). The production of two enzymes, spiramycin I-3 hydroxyl acylase ${ }^{8)}$ and TDP-mycarose synthetase ${ }^{9)}$ in strains AF30 and S-1 were comparable to those of strain KA-1028. From this evidence we conclude that at some stage before the formation of forocidin I (4), in the biosynthesis of spiramycin, one or more plasmid-encoded functions are required.

\section{SATOSHI ŌMURA \\ HARUO IKEDA \\ CHIAKI KITAO}

School of Pharmaceutical Sciences, Kitasato University

Minato-ku, Tokyo 108, Japan

(Received June 1, 1979)

\section{References}

1) Hopwood, D. A. \& M. J. Merrick: Genetics of antibiotics production. Bact. Rev. 41: 595 635, 1977

2) Yagisawa, M.; T-S. R. Huang \& J. E. Davies: Possible involvement of plasmids in biosynthesis of neomycin. J. Antibiotics 31: 809 813, 1978

3) Ochi, K. \& E. KatZ: The possible involvement of a plasmid(s) in actinomycin synthesis by Streptomyces parvulus and Streptomyces antibiotics. J. Antibiotics 31: 1143 1148, 1978

4) Ōmura, S. \& A. Nakagawa: Chemical and biological studies on 16 -membered macrolide
Table 1. Characterizations of Streptomyces ambofaciens strains KA-1028, S-1 and AF-30

\begin{tabular}{l|c|c|c}
\hline & $\begin{array}{c}\text { KA-1028 } \\
\text { (parent } \\
\text { strain) }\end{array}$ & S-1 & AF-30 \\
\hline $\begin{array}{l}\text { Production of } \\
\text { spiramycin }(\mu \mathrm{g} / \mathrm{ml})\end{array}$ & 100 & 0 & 0 \\
$\begin{array}{l}\text { Transformation of } \\
\text { forocidin I into } \\
\text { spiramycin II }\end{array}$ & + & + & + \\
$\begin{array}{l}\text { Resistance to } \\
\text { spiramycin }(\mu \mathrm{g} / \mathrm{ml})\end{array}$ & $>800$ & $>800$ & $>800$ \\
$\begin{array}{l}\text { Formation of } \\
\text { soluble pigment* }\end{array}$ & + & - & - \\
$\begin{array}{l}\text { Formation of } \\
\text { aerial mycelium** }\end{array}$ & + & - & - \\
Color of colony*** & yellow & white & white \\
\hline
\end{tabular}

* Oatmeal agar medium (ShIRLING and GotTLIEB $^{10)}$ )

** Inorganic salts-starch agar medium (SHIRLING and GotTlieb ${ }^{10)}$ )

*** Glucose-CZAPEK agar medium $+1 \%$ casamino acid

antibiotics (Review article). J. Antibiotics 28: $401 \sim 433,1975$

5) Ömura, S.; C. Kitao, H. Hamada \& H. Ikeda: Final steps in the biosynthesis of spiramycin, using enzyme inhibitor: cerulenin. Chem. Pharm. Bull. 27: 176 182, 1979

6) Shaw, P. D. \& J. Piwowarski: Effects of ethidium bromide and acriflavine on streptomycin production by Streptomyces bikiniensis. J. Antibiotics 30: 404 408, 1977

7) Meyers, J. A.; D. Sanchez, L. P. Elwell \& S. FALKow: Simple agarose gel electrophoresis method for the identification and characterization of plasmid deoxyribonucleic acid. J. Bact. 127: 1529 1537, 1976

8) Ömura, S.; H. Ikeda \& C. Kitao: J. Biochem. submitted.

9) Pape, H. \& G. U. Brillinger: Biosyntheses von Thymidin-diphosphymycarose durch ein zellfreies System aus Streptomyces rimosus. Arch. Mikrobiol. 88: 25 35, 1973

10) Shirling, E. B. \& D. Gottlieb: Methods for characterization of Streptomyces species. Int. J. Syst. Bact. 16: 313 340, 1966 